\title{
Factors Contributing To The Unsuccessful Implementation Of The BSC In A South African Provincial Treasury Department
}

\author{
Chengedzai Mafini, Vaal University of Technology, South Africa \\ David R.I. Pooe, Vaal University of Technology, South Africa \\ Hebert Nqcobo, Vaal University of Technology, South Africa
}

\begin{abstract}
This study investigated the factors that contributed to the unsuccessful implementation of the Balanced Scorecard in a provincial government department in South Africa. The study was inspired by the unsatisfactory attempt to introduce the Balanced Scorecard as a performance measurement system in that department in the year 2009. Data were collected through a questionnaire comprising of two sections. The questionnaire was administered to 81 managers and employees who were on the approved establishment of the department in 2009. The factors contributing to the failure of the program were extracted using principal components analysis. An analysis of the descriptive statistics for each factor was also conducted. The findings of the study indicate that the failure of the Balanced Scorecard project may be linked to four factors; namely, inconsistencies within the project team, an ineffective communication strategy, myopic planning and poor execution. Among these factors, planning contributed the highest to the demise of the project. Using these findings as an anchor, the study recommended a number of strategies that may be adopted in in the event that public organisations intend to implement Balanced Scorecard programs in the future.
\end{abstract}

Keywords: Organisational performance, performance management, Balanced Scorecard, Government Department, South Africa

\section{INTRODUCTION}

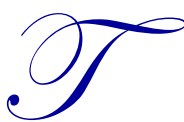

he aim of this study was to investigate the factors that contributed to the unsuccessful implementation of the Balanced Scorecard in a South African Provincial Treasury Department. The field of organisational dynamics continues to develop tremendously, involving numerous interesting topics that have attracted research interest for a long time (Niven, 2003). Among these topics is performance management, which is the process of creating a work environment or setting in which people are enabled to perform to the best of their abilities (Shahzad, Luqman, Khan \& Shbbir, 2012). Performance management can focus on the performance of an organisation, a department, employee, or even the processes to build a product or service, as well as many other areas (Mafini \& Pooe, 2013). On the overall, performance management is concerned with organisational performance, which per se, is the organisation's capability to accomplish its goals effectively and efficiently using resources (Short, Ketchen, Palmer \& Hult, 2007). Performance management therefore acts as an instrument through which the general concept of organisational performance may be understood.

In the context of the public sector in developing countries such as South Africa, performance management has become an important activity in organisational practice because most public organisations struggle to perform optimally (Mankins \& Steele, 2005). However, the measurement of performance in organisations is shrouded in controversy, since there are numerous performance management systems that have been developed over time (Short et al. 2007). However, among the performance measurement systems that have won the confidence of most scholars 
as well as experts in the field of performance management, is the Balanced Scorecard (BSC), which has gained prominence as a tool for both performance management as well as strategic management.

\section{THE BALANCED SCORECARD (BSC)}

The BSC is an instrument used for measuring and managing the overall performance of an organisation and that of employees at all levels of the organisational hierarchy (Asif, Bresson \& Moskowitz, 2007). As highlighted by its developers, Kaplan and Norton (1996) the BSC measures performance across the four balanced perspectives; namely, financial, customers, internal business processes, and learning perspectives. It provides managers with the instrumentation for navigating future competitive success and functions as the cornerstone of a company's current and future success (Molleman, 2007). Figure 1 illustrates a basic BSC:

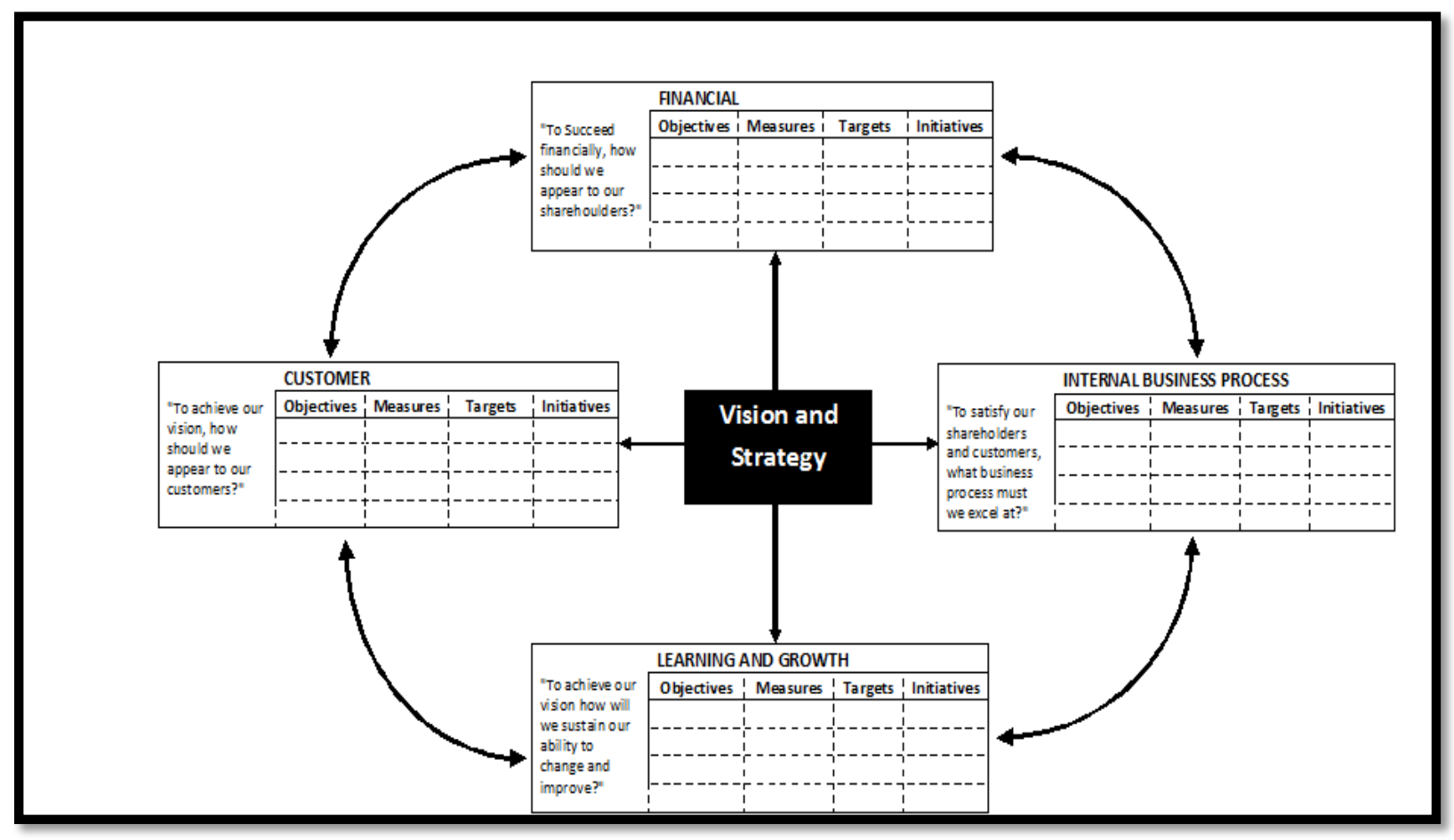

Source: (Kaplan \& Norton, 2010)

Figure 1: A Basic Balanced Scorecard

The (BSC) as a performance measurement and management system has won the confidence of most scholars and experts in the organisational settings, both in the private and public sectors (Johnsen, 2001). There several reasons for this domination. For instance, as suggested by Niven (2003) the BSC was developed through a careful selection of a set of quantifiable measures derived directly from an organisation's strategy, which makes it a multipurpose mechanism. The BSC acts as a systematic attempt to measure the relationship between the results and the operating activities of an organisation, and also as a powerful instrument to communicate the organisation's goals and objectives to operating managers (Norreklit, 2003). It offers managers a balanced presentation of both financial and operational measures (Kaplan \& Norton, 1992). Chan and Ho (2000) add that the BSC may be regarded as both a performance measurement and strategic management system. According to Niven (2006) the BSC assists organisations to overcome three key issues; namely, effective organisational performance measurement; the rise of intangible assets; and the challenge of implementing strategy. Therefore, the BSC, if implemented properly, is a versatile instrument capable of adding value to the organisation in several ways.

Paranjape, Rossiter and Pantano (2006) argue that the BSC, of all performance measuring systems, is the most popular, least criticised and widely implemented framework. Otley (1999) opines that the BSC approach of linking performance measures with business unit strategy could be its major strength. Lipe and Salterio (2000) 
concur that implementing the BSC should improve managerial decision making through the alignment of performance measures with the goals and strategies of the firm and the firm's business units. Furthermore, Pineno (2007) regards the right timing and marketing of the BSC as major contributing factor to its success. Marketing activities are critical and, as such, must be continuous since they involve making information available to the team members (employees, supervisors and managers) who will be responsible for developing or constructing the BSC, as well as management members and employees who will be responsible for its implementation (Perderson, 2002).

Despite its advantages, the BSC has shortcomings that have been identified by several scholars. Johnsen (2001) regards the BSC, to some extent, as an extended model of Management by Objectives (MBO). Norreklit (2003) challenges the BSC by asserting that long-term financial performance cannot be generically attributed to increased customer loyalty, and further argues that the promotion of the BSC through the use of rhetoric is not justifiable on any scientific grounds. Chang (2007) regards the inability of the public sector institutions to articulate their mission and associated strategies as a major challenge in implementing the Balanced Scorecard. Furthermore, Schalm (2007) highlights that scores of public sector institutions fail to implement the BSC successfully. It is logical then to assume that any public organisation may face challenges regarding the adoption of the BSC.

\section{PROBLEM STATEMENT}

A selected Provincial Government Department in South Africa adopted a position to introduce the BSC to all of its divisions with the prime intention of improving performance. This decision was taken during the 2009/10 financial year. It was envisaged that the BSC would replace the traditional performance management system that was in place at the time, which was the Performance Management and Development System (PMDS), to ensure efficiency and effectiveness in service delivery. It was also anticipated that the adoption of the BSC would facilitate the easier identification of the exact problem area/s whenever performance related issues were encountered, which would assist in instituting appropriate remedial action/s. However, the BSC program was ineffective after several attempts to introduce it in the department proved unsuccessful. The program was then dropped and the department continued with its use of the conventional performance management system. Since the later system has been in place for up to four decades, and has its own shortcomings, a need still exists to replace it with a more current and relevant performance management system, such as the BSC. This provides an impetus for conducting this study in the sense that before any attempt to re-introduce the BSC in the department, a need exists to diagnose the factors that contributed to the demise of the first attempt. The identification of the factors contributing to the failure of the BSC program cannot be left to speculation but have to be explored empirically. Once these contributory factors have been identified, it becomes easier to implement another BSC program without reinventing the wheel of failure. Remarkably, there is scant empirical evidence on the unsatisfactory implementation of the BSC program in the provincial government department in question. This study attempts to address this gap and provide new scientific evidence to this matter. Therefore, the purpose of the study was to determine the factors that contributed to the unsuccessful implementation of the BSC in a South African Provincial Treasury Department. The study is important in that it provides management with information that could be useful to public organisations in drawing up strategies for the successful implementation of performance management programmes in their own contexts.

\section{METHOD}

\section{Research Approach}

The research design encompassed both a review of the literature and an empirical study. It was deemed important to conduct a review of related literature as this would strengthen the procedure to be used, restrict data collection to what is of material value to the study and help in data verification (Babbie, 2010). Various literature related to the topic under study were therefore reviewed; most of which related to the subject of the BSC, and were sourced from journal articles, textbooks, magazines, newspapers, and the Internet.

\section{Empirical Study}

The empirical part of the study involved a number of protocols such as the selection of the sample entities, instrumentation, statistical analysis and ethical considerations. 


\section{Participants}

The target population was composed of management and employees of the South African Provincial Treasury Department's approved establishment during 2009/10 financial years, which is the period when the BSC program was unsuccessfully implemented. This population consisted of 1090 individuals. The actual sample consisted of 81 individuals who were selected using the non- probability availability method. The availability technique was chosen for this study in order to counter possible challenges regarding some members of the population who were difficult to reach due to, among others, geographical dispersion.

\section{Instrumentation And Data Collection Methods}

Primary data were collected by means of a structured two- section questionnaire. The questionnaire was designed in order to meet the objectives of the research. To reduce any inconsistencies within the questionnaire, a pre-test involving 15 respondents, followed by a pilot study involving 20 respondents, were conducted, in accordance with the recommendation by Cooper and Schindler (2008). Both the pre-test sample as well and the pilot test sample were selected using the availability technique. As mentioned before, the final questionnaire was partitioned into two sections. The first section was designed to elicit the respondent's biographical information, while the second section was designed to elicit information pertaining to various aspects regarding the implementation of the BSC within the government department in question. Likert-scale type questions, ranging from 1- strongly agree to 5- strongly disagree were used in the second section of the questionnaire.

\section{Ethical Considerations}

A number of ethical considerations were adhered to during the study. Permission to conduct the study was obtained from the government department in question prior to the commencement of the study. Respondents were neither forced nor coaxed to participate in the research, but did so voluntarily, through their informed consent. The principle of non-disclosure was followed as the identities of the respondents were not revealed. It was also agreed that the research results would not be made available for use outside the agreement made with respondents. In addition to the aforementioned aspects, all sources from which the information was obtained were acknowledged, as suggested by Goddard and Melville (2005).

\section{Statistical Analysis}

Basic descriptive statistics such as the mean, median, mode, and standard deviations, among others, were used as the primary vehicles in the analysis of the collected data. To facilitate this process, a combination of two computerised statistical packages; MS Excel and Statistical Package for the Social Sciences (SPSS version 21.0) were employed.

\section{RESEARCH RESULTS}

\section{Biographic Profile Of Respondents}

An analysis of the gender of respondents revealed that $40.2 \%(n=33)$ of respondents were males whereas $59.8 \%(\mathrm{n}=49)$ were female. After collapsing the respondents' ages, it emerged that $9.8 \%(\mathrm{n}=8)$ fell in the 26 to 35 years age category, $32.9 \%(n=27)$ fell in the 36 to 45 years category, $40.2 \%(n=33)$ fell in the 46 to 55 age cohort and $17.1 \%(\mathrm{n}=14)$ were at least 56 years old. In terms of their tenure in the department at the time the BSC was introduced to the department, 9.8\% $(\mathrm{n}=8)$ had been employed for less than 2 years, $14.6 \%(\mathrm{n}=12)$ had between 2 to 5 years of service, $25.6 \%(\mathrm{n}=21)$ had between 6 to 9 years of completed service, and $50 \%(\mathrm{n}=41)$ had been in the department for more than 9 years. With reference to the type of employment contract, a majority of the respondents $(95.1 \% ; n=78)$ were permanent staff. With regard to the level of formal education, $46.3 \%(n=38)$ of the respondents had a matric $2.4 \%(n=2)$ held certificates, $20.7 \%(n=17)$ possessed diplomas, $17.1 \%(n=14)$ were holders of Degrees and $13.4 \%(\mathrm{n}=11)$ had postgraduate qualifications. Approximately $3.7 \%(\mathrm{n}=3)$ occupied executive management positions in the department, $8.5 \%(\mathrm{n}=7)$ were senior managers, $25.6 \%(\mathrm{n}=21)$ were middle managers, $18.3 \%(\mathrm{n}=15)$ 
were line managers, $9.8 \%(n=8)$ fell in the category of specialist staff, $30.5 \%(n=25)$ were clerical/administrative staff, and $3.7 \%(n=3)$ fell in the category of other staff.

\section{Validity and Reliability}

Green, Caracelli and Graham (1989) define validity as the degree to which an instrument measures what it is supposed to measure. The same authors define reliability as the extent to which a test or a procedure produces similar results under constant conditions. In this study, validity was ascertained through conducting a pre-test with 15 respondents. Since no previous instrument had been developed such a questionnaire was developed specifically for this study, pre-testing was followed by the pilot testing of 20 questionnaires to establish the reliability of the instrument. Content, construct, convergent and predictive validities were assessed by an evaluation of the questionnaire by experts in the field. To ascertain the reliability of the questionnaire, the Cronbach alpha was used. According to Blanche, Durrheim and Painter (2006), an alpha value greater than 0.70 indicates that questionnaire type scales are internally consistent (reliable). In the current study, an overall scale reliability of 0.84 as measured by the Cronbach alpha was attained, which attests to the satisfactory internal consistency of the scale.

\section{Extraction of Factors Contributing the Failure of the BSC Project}

The factors extracted in the study comprised four dimensions that accounted for $57 \%$ of the variance explained by the factors. These factors were computed through the Principal Component Analysis (PCA) using Varimax rotation. The naming of the factors and the description is reported in Table 1.

Table 1: Factors Contributing To The Unsuccessful Implementation Of The BSC Project

\begin{tabular}{|c|c|c|c|}
\hline Factor & Label & Cronbach Alpha & \begin{tabular}{|c|} 
Operational Description \\
\end{tabular} \\
\hline 1 & Project team & 0.867 & $\begin{array}{l}\text { This refers to the levels of skills and expertise as well as the } \\
\text { involvement of the individuals and groups involved in the } \\
\text { BSC project }\end{array}$ \\
\hline 2 & Planning & 0.831 & $\begin{array}{l}\text { This refers to the preparation for the implementation of the } \\
\text { BSC. }\end{array}$ \\
\hline 3 & Communication & 0.848 & $\begin{array}{l}\text { This refers to the manner in which the BSC was marketed to } \\
\text { all stakeholders in order to obtain their support. }\end{array}$ \\
\hline 4 & Execution & 0.785 & $\begin{array}{l}\text { This refers to activities involved in the actual implementation } \\
\text { of the BSC project as well as the general attitudes toward the } \\
\text { BSC. }\end{array}$ \\
\hline
\end{tabular}

The summated means of the factors contributing to the unsuccessful implementation of the BSC project were computed to establish the mean ranking of the dimensions in terms of importance rating. The results are reported in Table 2.

Table 2: Means, Standard Deviation And Mean Ranking Of Factors

\begin{tabular}{lcccc}
\hline \multicolumn{1}{c}{ Factor } & N & Std. Deviation & Mean & Mean Ranking \\
\hline Project Team & 81 & 0.792 & 2.964 & 3 \\
Planning & 81 & 0.724 & 3.935 & 1 \\
Communication & 81 & 0.738 & 3.816 & 2 \\
Execution & 81 & 0.705 & 2.713 & 4 \\
\hline Scale: 1=Strongly disagree; 5= Strongly agree & & & \\
\hline
\end{tabular}

An analysis of Table 2 shows that the means of the factors ranged between 2.713 and 2.964. In the ranking of the mean scores, planning $(\bar{x} \geq 3.935)$ emerged as the highest scoring factor, with execution $\left(\bar{x}_{\geq} 2.713\right)$ occupying the bottom-most position. This result demonstrates that amongst the factors extracted in this study, planning contributed most to the unsuccessful implementation of the BSC project and execution contributed the least. 


\section{Analysis of Frequencies}

\section{Factor 1: The Project Team}

The respondents' perceptions regarding the BSC project team are reported in Table 3.

Table 3: Frequencies On Perceptions Regarding The Project Team

\begin{tabular}{|c|c|c|c|c|c|c|}
\hline Item & Description & $\begin{array}{c}\text { Strongly } \\
\text { Disagree }(\%)\end{array}$ & $\begin{array}{c}\text { Disagree } \\
(\%)\end{array}$ & $\begin{array}{c}\text { Neutral } \\
(\%)\end{array}$ & $\begin{array}{c}\text { Agree } \\
(\%)\end{array}$ & $\begin{array}{c}\text { Strongly Agree } \\
(\%)\end{array}$ \\
\hline B17 & $\begin{array}{l}\text { Senior managers were } \\
\text { involved in the } \\
\text { development of the BSC }\end{array}$ & $3(3.7)$ & $57(70.4)$ & $11(3.6)$ & $10(12.3)$ & $00(00)$ \\
\hline B19 & $\begin{array}{l}\text { Implementing the BSC } \\
\text { required a lot of manpower }\end{array}$ & $6(7.4)$ & $6(7.4)$ & $2(2.5)$ & $16(19.8)$ & $51(63.0)$ \\
\hline B21 & $\begin{array}{l}\text { The manager in charge of } \\
\text { the BSC program was } \\
\text { suitably qualified }\end{array}$ & $56(69.1)$ & 11(13.6) & $2(2.5)$ & $12(14.8)$ & $00(00)$ \\
\hline B22 & $\begin{array}{l}\text { The BSC was developed by } \\
\text { qualified consultants }\end{array}$ & $2(2.5)$ & $61(75.3)$ & $3(3.7)$ & $12(14.8)$ & $3(3.7)$ \\
\hline B26 & $\begin{array}{l}\text { The BSC program team } \\
\text { was composed of capable } \\
\text { staff }\end{array}$ & $57(70.4)$ & $6(7.4)$ & $5(6.2)$ & 11(13.6) & $2(2.5)$ \\
\hline B27 & $\begin{array}{l}\text { The BSC program team } \\
\text { members worked together } \\
\text { very well }\end{array}$ & $8(9.9)$ & $7(8.6)$ & $56(69.1)$ & $9(11.1)$ & $1(1.2)$ \\
\hline B32 & $\begin{array}{l}\text { The BSC was implemented } \\
\text { by experts }\end{array}$ & $52(64.2)$ & $5(6.2)$ & $2(2.5)$ & $8(9.9)$ & $14(17.3)$ \\
\hline
\end{tabular}

An analysis of the results yielded several inconsistencies associated with the human resource function's involvement in the BSC project. As indicated by approximately $74 \%(\mathrm{n}=60)$ of the respondents, senior managers of the department were not actively involved in the BSC project. The absence of senior managers is a natural albatross to any organisational program (Smith, 2006). The program also required enormous manpower investments, which the department probably could not meet, as echoed by $83 \%(\mathrm{n}=67)$ of the respondents. Moreover, the skills and capabilities of those in charge of the program were inadequate to meet the demands of a program of such a magnitude as the BSC project. This is exhibited by the fact that a majority of the respondents $(83 \% ; n=67)$ doubted the abilities of the manager who was in charge of the program while $78 \%(n=63)$ cast aspersion on the skills of both the consultants who developed the BSC to be used in the department as well as the team that spearheaded the program.

Generally, performance management systems must be resident within the training and development component or sub-component and manned with appropriately qualified officials or practitioners (Robbins, Odendaal \& Roodt, 2004). Alternatively, performance management can be operated under the auspices of Human Resource Utilisation and Capacity Building sub-function that in turn reports to Human Resource Management and Development Business Unit (Kaplan \& Norton, 2001). This deportment typically ensures that technical as well as generic skills and competencies are addressed which are crucial in addressing effectiveness and efficiency of the organisation through its human resources (Rompho, 2011). It appears that in the case under scrutiny, this best practice was disregarded, which lead to the secondment as well as the employment of under qualified individuals and groups to run the BSC project.

\section{Factor 2: Planning}

The respondents' perceptions regarding planning are reported in Table 4. 
Table 4: Frequencies on Perceptions Regarding Planning

\begin{tabular}{|c|c|c|c|c|c|c|}
\hline Item & Description & $\begin{array}{c}\text { Strongly } \\
\text { Disagree (\%) }\end{array}$ & $\begin{array}{c}\text { Disagree } \\
(\%)\end{array}$ & $\begin{array}{c}\text { Neutral } \\
(\%)\end{array}$ & $\begin{array}{c}\text { Agree } \\
(\%)\end{array}$ & $\begin{array}{c}\text { Strongly Agree } \\
(\%)\end{array}$ \\
\hline B7 & $\begin{array}{l}\text { The BSC was linked to the } \\
\text { mission and vision of the } \\
\text { department }\end{array}$ & $2(2.5)$ & $52(64.2)$ & $8(9.9)$ & $18(22.2)$ & $1(1.2)$ \\
\hline B11 & $\begin{array}{l}\text { The BSC was linked to the } \\
\text { strategic objectives of the } \\
\text { department }\end{array}$ & $4(4.9)$ & $59(72.8)$ & $9(11.1)$ & $8(9.9)$ & $1(1.2)$ \\
\hline B16 & $\begin{array}{l}\text { The reward system was } \\
\text { linked to the BSC }\end{array}$ & $64(79.0)$ & $4(4.9)$ & $3(3.7)$ & $10(12.3)$ & $0(00)$ \\
\hline B24 & $\begin{array}{l}\text { Proper objectives were } \\
\text { developed to implement the } \\
\text { BSC }\end{array}$ & $64(79.0)$ & $5(6.2)$ & $4(4.9)$ & $8(9.9)$ & $0(00)$ \\
\hline B25 & $\begin{array}{l}\text { I believe that the BSC can } \\
\text { assist planners in the } \\
\text { department to identify what } \\
\text { should be done and } \\
\text { measured }\end{array}$ & $6(7.4)$ & $4(7.9)$ & $0(00)$ & $23(28.4)$ & $48(59.3)$ \\
\hline B28 & $\begin{array}{l}\text { The department was fully } \\
\text { prepared to implement the } \\
\text { BSC }\end{array}$ & $48(59.3)$ & $9(11.1)$ & $12(14.8)$ & $15(14.8)$ & $0(00)$ \\
\hline B29 & $\begin{array}{l}\text { The outcome measures as } \\
\text { well as performance drivers } \\
\text { were identified }\end{array}$ & $6(7.4)$ & $2(2.5)$ & $58(71.6)$ & $15(18.5)$ & $0(00)$ \\
\hline
\end{tabular}

In the study, it emerged that the planning of the BSC project was ineffective, as revealed through the existence of a cocktail of malfunctions that may be linked to planning. For instance, $67 \%(\mathrm{n}=54)$ of the respondents did not concur that the BSC was linked to the mission and vision of the department. Another 78\% (n=63) professed that the BSC was not linked to the strategic objectives of the department. Additionally, at least $84 \%(\mathrm{n}=68)$ maintained that the BSC was not linked to the reward system. Approximately $70 \%(n=57)$ of the respondents also affirmed that the department was ill-prepared to implement the BSC.

The failure by many public organisations to successfully implement the BSC has previously been linked to the inability to properly plan for the project. It is also commonly acknowledged that "Failure to plan is tantamount to planning to fail", as upheld by Van der Waldt and DuToit (2005). The incapability of public sector institutions to articulate their mission and associated strategies presents a major challenge in implementing the BSC (Chang, 2007). Moreover, as observed by Schalm (2007), scores of public sector institutions fail to implement the BSC successfully. The failure to link the BSC to the reward system is a potential source of conflict as employees may feel that successful implementation of the BSC program can result in reduced remuneration for them. It appears then that poor all-round planning is indeed a major factor behind the unsuccessful implementation of the BSC program in the Provincial Government department under study.

\section{Factor 3: Communication}

The respondents' perceptions regarding communication issues are reported in Table 5. 
Table 5: Frequencies Regarding Communication

\begin{tabular}{|c|c|c|c|c|c|c|}
\hline Item & Description & $\begin{array}{c}\text { Strongly } \\
\text { Disagree (\%) }\end{array}$ & $\begin{array}{c}\text { Disagree } \\
(\%)\end{array}$ & $\begin{array}{c}\text { Neutral } \\
(\%)\end{array}$ & $\begin{array}{c}\text { Agree } \\
(\%)\end{array}$ & $\begin{array}{c}\text { Strongly Agree } \\
(\%)\end{array}$ \\
\hline B1 & $\begin{array}{l}\text { The reasons why the BSC } \\
\text { was introduced in the } \\
\text { department were clearly } \\
\text { explained }\end{array}$ & $20(24.7)$ & $25(30.9)$ & $21(25.9)$ & $14(17.3)$ & $1(1.2)$ \\
\hline B2 & $\begin{array}{l}\text { The benefits associated with } \\
\text { the BSC were clearly } \\
\text { explained }\end{array}$ & $27(33.3)$ & $17(21.0)$ & $16(19.8)$ & $1(1.2)$ & $20(24.7)$ \\
\hline B5 & $\begin{array}{l}\text { The linkage between the } \\
\text { strategic focus of the } \\
\text { department and the Batho } \\
\text { Pele principles was clearly } \\
\text { explained }\end{array}$ & $7(8.6)$ & $47(58.0)$ & $1(1.2)$ & $19(23.5)$ & $7(8.6)$ \\
\hline B6 & $\begin{array}{l}\text { The difference between the } \\
\text { performance management } \\
\text { that was in place at the time } \\
\text { and the BSC was clearly } \\
\text { explained }\end{array}$ & $16(19.8)$ & $27(33.3)$ & $24(29.6)$ & $14(17.3)$ & $0(00)$ \\
\hline B8 & $\begin{array}{l}\text { The degree to which the } \\
\text { BSC would incorporate the } \\
\text { operational measures that } \\
\text { would drive future } \\
\text { performance was explained }\end{array}$ & $42(51.9)$ & $8(9.9)$ & $10(12.4)$ & $10(12.4)$ & 11(13.6) \\
\hline B9 & $\begin{array}{l}\text { The support of senior } \\
\text { management was secured }\end{array}$ & $12(14.8)$ & $26(32.1)$ & $27(33.3)$ & $6(7.4)$ & $10(12.4)$ \\
\hline B12 & $\begin{array}{l}\text { I understand the factors that } \\
\text { are important for the BSC to } \\
\text { succeed }\end{array}$ & $8(9.9)$ & $8(9.9)$ & $36(44.4)$ & $27(33.3)$ & $2(2.5)$ \\
\hline B14 & $\begin{array}{l}\text { There was an adequate } \\
\text { explanation of how the } \\
\text { BSC is important to my } \\
\text { specific areas of } \\
\text { functionality }\end{array}$ & $18(22.2)$ & $23(28.4)$ & $34(42.0)$ & $6(7.4)$ & $0(0.00)$ \\
\hline B15 & $\begin{array}{l}\text { I was taught how to use } \\
\text { a BSC }\end{array}$ & $35(43.2)$ & $27(33.3)$ & $14(17.3)$ & $0(00)$ & $5(6.2)$ \\
\hline
\end{tabular}

An analysis of Table 3 gave an expose' of several communication issues that contributed to the demise of the BSC program in the Provincial Government Department. Approximately 56\% ( $\mathrm{n}=69)$ of the respondents indicated that the reasons behind the introduction of the BSC in the department were not adequately explained to them. A further 54\% ( $\mathrm{n}=67)$ professed ignorance toward the benefits associated with the use of the BSC. Approximately 53\% ( $\mathrm{n}=65)$ of respondents perceived that they could not understand the difference between the performance system that was in use at that time and the BSC. A large number of the respondents $(46 \% ; n=37)$ highlighted that the program was implemented without the support of senior management. Additionally, most respondents $(76 \% ; n=62)$ indicated that they did not possess the skills required in using a BSC whilst approximately $51 \%(n=41)$ perceived that the importance of the BSC to their specific areas of functionality was inadequately explained to them prior to the implementation of the program.

The findings of this study demonstrate that information sessions that were held in the department to market the BSC program were fundamentally ineffective. Consequently, most of the internal stakeholders did not benefit from these marketing attempts, a factor which contributed to the eventual failure of the program. As suggested by Pineno (2007) marketing is a very powerful instrument as it is not only intended to make people get information pertaining to the new venture, but also assists in getting support or buy-in for all respective role-players. The right timing and marketing of the BSC partly contributes to its success Kallás (2006). Therefore, the possibility that the BSC would have been successful could have been enhanced significantly by marketing the program effectively to the entire inventory of management and employees in the department. 


\section{Factor 4: Execution}

The respondents' perceptions regarding the execution factor are reported in Table 6 .

Table 6: Frequencies On Perceptions Regarding Execution

\begin{tabular}{|c|c|c|c|c|c|c|}
\hline Item & Description & $\begin{array}{c}\text { Strongly } \\
\text { Disagree }(\%)\end{array}$ & $\begin{array}{c}\text { Disagree } \\
(\%)\end{array}$ & $\begin{array}{c}\text { Neutral } \\
(\%)\end{array}$ & $\begin{array}{c}\text { Agree } \\
(\%)\end{array}$ & $\begin{array}{c}\text { Strongly Agree } \\
(\%)\end{array}$ \\
\hline B3 & $\begin{array}{l}\text { I feel that the BSC is an } \\
\text { effective performance } \\
\text { management tool }\end{array}$ & $4(4.9)$ & $2(2.5)$ & $12(14.8)$ & $17(21.0)$ & $46(56.8)$ \\
\hline B4 & $\begin{array}{l}\text { The BSC was going to be } \\
\text { introduced to all } \\
\text { departments at the same } \\
\text { time }\end{array}$ & $4(4.9)$ & $14(17.3)$ & $52(64.5)$ & 11(13.6) & $0(00)$ \\
\hline B13 & $\begin{array}{l}\text { I feel that the BSC should } \\
\text { be reintroduced in the } \\
\text { department }\end{array}$ & $9(11.1)$ & $6(7.4)$ & $5(6.2)$ & $40(49.4)$ & $21(25.9)$ \\
\hline B18 & $\begin{array}{l}\text { Specific Computer software } \\
\text { were used to implement the } \\
\text { BSC }\end{array}$ & $20(24.7)$ & $57(70.4)$ & $4(4.9)$ & $0(00)$ & $0(00)$ \\
\hline B23 & $\begin{array}{l}\text { I feel that the effective } \\
\text { implementation of the BSC } \\
\text { may enable the department } \\
\text { to perform better }\end{array}$ & $4(4.9)$ & $9(11.1)$ & $3(3.7)$ & $47(58.0)$ & $18(22.2)$ \\
\hline B30 & $\begin{array}{l}\text { I feel that proper } \\
\text { implementation of the BSC } \\
\text { can lead to the continuous } \\
\text { improvement of strategic } \\
\text { performance and results in } \\
\text { the department } \\
\text { The implementation of the }\end{array}$ & $3(3.7)$ & $4(4.9)$ & $2(2.5)$ & $52(64.2)$ & $20(24.7)$ \\
\hline B31 & $\begin{array}{l}\text { BSC was done } \\
\text { electronically }\end{array}$ & $47(58.0)$ & $27(33.3)$ & $1(1.2)$ & $4(4.9)$ & $2(2.5)$ \\
\hline B33 & $\begin{array}{l}\text { Implementation of the BSc } \\
\text { was benchmarked against } \\
\text { other organisations that had } \\
\text { been successful in } \\
\text { implementing it }\end{array}$ & $31(38.27)$ & $28(43.57)$ & $6(7.4)$ & $9(11.1)$ & $7(8.64)$ \\
\hline
\end{tabular}

With regard to the execution of the BSC project, there was an almost unanimous $(95 \% ; n=77)$ view that there was limited use of relevant computer software applications in the program. It also emerged that the BSC was not benchmarked against other organisations, as indicated by $82 \%(n=59)$ of the respondents. These two findings demonstrate the hesitancy by those in charge of the project to adhere to best practice. Since any system that involves people is susceptible to bias and manipulation, it is necessary to use available BSC software to avoid these elements during implementation (Johnsen, 2001). In addition, it is generally recommended that benchmarking with other organisations be conducted prior to the implementation of a BSC project in order to learn from them (Kaplan \& Norton, 1992).

Perhaps the most notable feature in this section is the optimism expressed by the respondents regarding future implementation of the BSC in the department. Approximately $75 \%(n=61)$ of the respondents perceived that it is necessary to launch another BSC program in the department. A majority of the respondents (78\%; $\mathrm{n}=64)$ felt that the BSC is an effective performance management tool while another $80 \%(n=65)$ felt that the successful implementation of the BSC may enable the department to perform better. Such responses offer a glimpse of hope that the department should initiate another BSC program, albeit after addressing the bottlenecks identified in this study. 


\section{CONCLUSIONS}

The main purpose of the study was to determine the factors that contributed to the unsuccessful implementation of the BSC in a South African Provincial Treasury Department. Four factors; namely, the project team, planning, communication and execution were identified as the driving forces behind the failure of the program. More specifically, the following emerged as dominant sub-factors;

- $\quad$ The BSC was not properly marketed within the department to ensure that management and employees clearly understood the BSC concept and the value it would add to the department's operations.

- $\quad$ The support of senior management and other strategic constituencies who were going to be affected by the successful implementation of the BSC was not secured prior to the initiation of the program.

- $\quad$ There was no comprehensive plan for marketing the BSC program as well as for ensuring the existence of synergy between the BSC and the performance management system that was in place at that time.

- $\quad$ The role to be performed by consultants who developed the BSC was obscure. Had the role of the consultants been clarified, it would have been easier to identify challenges that were going to be experienced during the implementation process.

- $\quad$ There are doubt on the levels of skill and expertise of the officials who conducted the BSC orientation workshops.

- $\quad$ There was no multidisciplinary team or committee composed of individuals from various sections of the department that was selected to oversee the implementation of the BSC.

\section{RECOMMENDATIONS}

In general, the introduction of the BSC constitutes a 'cultural change initiative' (Bloomfield 2002) that represents a paradigm shift with regard to the performance management approach adopted in the organisations. In view of this, the department should have employed change management techniques to ensure that the BSC was widely accepted by the employees at operational and management levels. With reference to the marketing of the program, it would have been helpful to obtain the support or buy-in of all managers and employees prior to the implementation of the program. In the implementation of the BSC system, it was necessary to assure employees that the reward system was linked to the BSC, and was be able to reward excellent individual and group performances. Through this posture, the support of employees would have been secured. Furthermore, the marketing of the BSC program should have been preceded by benchmarking the idea with the organisations that had previously successfully implemented similar systems, with a view to benefitting from their best practices, as prescribed by Johnsen (2001).

With regard to the apparent skills and expertise deficiencies exhibited by those in charge of the program, it is necessary that only individuals, both internal as well as external consultants, who are tried and tested in terms of their competencies are employed to spearhead all organisational programs. The use of modern information and communication technologies (ICT) must be embedded in the implementation of BSC-related systems (Schalm, 2007). This will reduce the effects of human error, bias and manipulation from those involved in executing the program. The BSC program must also be run through the oversight of a well-balanced cross-functional team. This approach finds support in Dayaram and Fung's (2012) observation that the team approach is more appropriate because organisations are able to benefit from the rich repertoire of knowledge that exists within the workforce when there is collaboration and sharing of knowledge. Last but not least, sustained monitoring and evaluation is paramount at all stages in these processes to ensure that the project continues to add values to the organisation (Lewis, 2007).

\section{LIMITATIONS AND IMPLICATIONS FOR FURTHER RESEARCH}

It is common that research papers produced are affected by some limitations which make them imperfect in one way or another. This study is no exception. First, the study was based on a limited number of respondents, which makes it difficult to generalise the findings to other populations and contexts. Second, since researcher who administered the questionnaires was known to the respondents, it is possible that some respondents were more subjective than objective in their responses in the questionnaire. Additionally, some respondents were unwilling to 
participate in the study because they did not know anything about the BSC. Fourth, the exclusive reliance on descriptive statistics in the data analysis is also acknowledged.

The study has several implications for further research. Similar studies can be conducted in other government departments where comparable challenges have been experienced in the past. Future studies can be conducted using an increased number of respondents, thereby making the results easier to generalise. Moreover, more rigorous data analysis techniques can be conducted on the same study, to measure the impact of the identified factors on each other. It would also be interesting to conduct future studies on this topic using the mixed method approach that combines quantitative and qualitative approaches. This could ensure that more comprehensive responses emanating from the use of interviews for more clarity and follow-up questions on responses received through the questionnaire.

\section{REFERENCES}

1. Asif, M., Bresson, C., \& Moskowitz, M. (2007). IT framework for the implementation of balanced scorecard in health systems: application Big and Small. Retrieved January 21, 2014 from: http://www.nesug.org/proceedings/nesug07/ap/ap20.pdf.

2. $\quad$ Babbie, E. (2010). The practice of social research.12 $2^{\text {th }}$ ed. Belmont, Wadsworth: Cengage Learning.

3. Blanche, T.M., Durrheim, K., \& Painter D. (2006). Research in practice: applied methods for social sciences. Cape Town: University of Cape Town Press.

4. Chan, Y.L., \& Ho, S.K. (2000). The use of Balanced Scorecard in a Canadian hospital. Retrieved October 5, 2011 from: http//www.aaahq.org/northeast/2000/q17/pdf.

5. Chang, A. (2007). Balanced Scorecard implementation in the public sector: lessons learnt in a large local government authority. Retrieved October 6, 2011 from: http://www.afaanz.org/openconf/2009/modules/request.php?module=oc_program\&action=view.php\&id=2 $\underline{28}$

6. $\quad$ Cooper, D.R. \& Schindler, P.S. (2008). Business research methods. $2^{\text {nd }}$ ed. Singapore: McGraw-Hill.

7. Dayaram, K., \& Fung, L. (2012). Team performance: where learning makes the greatest impact. Retrieved January 29, 2013 from: http://rphrm.edu.au/2012/issue1/learning.html.

8. Goddard, W., \& Melville, S. (2005). Research methodology: an introduction. $2^{\text {nd }}$ ed. Lansdowne: Juta \& Co.

9. Greene, J. C., Caracelli, V. J., \& Graham, W. F. (1989). Toward a conceptual framework for mixed-method evaluation designs. Educational Evaluation and Policy Analysis, 11(3), 255-274.

10. Johnsen, A. (2001). Balanced scorecard: theoretical perspectives and public management implications. Managerial Auditing Journal, 16(6), 319-330.

11. Kallás, I., \& Sauaia, A.C.A. (2006). Balanced Scorecard implementation for strategy management: variation of manager opinion in real and simulated companies. Retrieved February 6, 2014 from: http://www.sbaweb.wayne.edu/ absel/bkl/\%5Cvol133\%5C33bc.pdf.

12. Kaplan, R.S., \& Norton, D.P. (1992). The Balanced Scorecard-measures that drive performance. Boston: Harvard Business Review Press.

13. Kaplan, R.S., \& Norton, D.P. (1996). Using the Balanced Scorecard as a strategic management system. Boston: Harvard Business Review.

14. Kaplan, R.S., \& Norton, D.P. (2001). The strategy-focused organization: how Balanced Scorecard companies thrive in the new business environment. Boston: Harvard Business Review Press.

15. Kaplan, R.S., \& Norton, D.P. (2010). Conceptual foundations of the Balanced Scorecard. Boston: Harvard Business Review Press.

16. Lewis, J.P. (2007). Fundamentals of project management. $3^{\text {rd }}$ ed. New York: Amacom.

17. Lipe, M.G., \& Salterio, S.E. (2000). The Balanced Scorecard: judgmental effects of common and unique performance measures. The Accounting Review, 75(3), 283-298.

18. Mafini, C., \& Pooe, D.R.I. (2013). Performance measurement in a South African government social services department: a Balanced Scorecard approach. A Mediterranean Journal of Social Science, 4(14), 2039-2117.

19. Mankins, M.C., \& Steele, R. (2005). Turning great strategy into performance. Boston: Harvard Business Review Press. 
20. Molleman, B. (2007). The Challenge of implementing the Balanced Scorecard. Retrieved January 27, 2013 from: http:// www.slc.co.ke/sites/.../the-challenge-of-implementing-the-balanced-scorecard.

21. Niven, P. R. (2003). Balanced Scorecard: step-by-step for Government and Non-profit Agencies. New Jersey: John Wiley \& Sons.

22. Niven, P.R. (2006). Balanced scorecard step-by-step: maximizing performance and maintaining results. $2^{\text {nd }}$ ed. New Jersey: John Wiley \& Sons.

23. Norreklit, H. (2003). The Balanced Scorecard: what is the score? A rhetoric analysis of the Balanced Scorecard. Retrieved October 6, 2011 from: http://citeseerx.ist.psu.edu/viewdoc/summary?doi=10.1.1.117.9317.

24. Otley, D. (1999). Performance management: a framework for management control systems research. Management Accounting Research, 10, 363-382.

25. Paranjape, B., Rossiter, M. \& Pantano, V. (2006). Insights from the Balanced Scorecard performance measurement systems: success, failures and future - a review. Measuring Business Excellence, 10(3), 4-14.

26. Pederson, L.M. (2002). Performance-oriented management: a practical guide for government agencies. Vienna. Virginia. Management Concepts, Inc.

27. Pineno, C.J. (2007). The business school strategy: continuous improvement by implementing the Balanced Scorecard. Retrieved February 6, 2014 from: http://www.jupapadoc.startlogic.com/manuscripts/08016.pdf.

28. Robbins, S.P., Odendaal, A., \& Roodt, G. (2004). Organisational behaviour: global and Southern African perspectives. Cape Town: Pearson Education South Africa.

29. Rompho, N. (2011). Why the Balanced Scorecard fails in SMEs: a case study. International Journal of Business and Management, 10, 6- 11.

30. Schalm, C. (2007). Developing and Implementing a Balanced Scorecard in a Long Term Care Organization. Retrieved October 4, 2011 from: http://www.cchse.org/.../Corine\%Schalm\%20Executive\%20Summary\%20Web\%20April.

31. Shahzad, F., Luqman, R.A., Khan, A.R., \& Shabbir, L. (2012). Impact of organizational culture on organizational performance: an overview. Interdisciplinary Journal of Contemporary Research in Business. 3(9), 139-156.

32. Short, J.C., Ketchen, D.J., Palmer, T.B., \& Hult, G.T.M. (2007). Organization, strategic group and industry influences on performance. Strategic Management Journal, 28(3), 147-167.

33. Smith, J.M. (2006). Using a Balanced Scorecard as a strategic tool in public purchasing. International Public Procurement Proceedings. Retrieved January 21, 2014 from: http://www.ippa.ws/PPC2/PROCEEDINGS/Article 36_Smith.pdf.

34. Van Der Waldt, G., \& Du Toit, D.F.P. 2005. Managing for excellence in the public sector. $2^{\text {nd }}$ ed. Cape Town: Juta\&Co,Ltd. 